\title{
COMPARISON OF THE PARAMETERS OF SIGNALS WITH EXTERNAL ILLUMINATION FOR SUPERVISION OF THE AREA FOR THE PROTECTION OF IMPORTANT STATE OBJECTS
}

\author{
Stanislav Horielyshev \\ Scientific and Research Center of Service and Military Activities \\ of the National Guard of Ukraine \\ port_6633@ukr.net \\ Igor Boikov \\ Department of Armoured Vehicles ${ }^{1}$ \\ biv543@ukr.net \\ Pavlo Volkov \\ Adjunct doctoral and adjunct ${ }^{1}$ \\ strong81007@gmail.com \\ Andrii Poberezhnyi \\ Scientific Research Center of Service and Military Activities of the National Guard of Ukraine ${ }^{I}$ \\ fix086@ukr.net \\ Aleksandr Kondratenko \\ Department of Armored Vehicles ${ }^{1}$ \\ apko_ko@ukr.net \\ ${ }^{1}$ National Academy of the National Guard of Ukraine \\ 3 Zakhysnykiv Ukrainy sq., Kharkiv, Ukraine, 61001
}

\begin{abstract}
In modern conditions, it becomes necessary to create security systems, surveillance systems, anti-terrorist systems that carry out covert detection and surveillance of small-sized ground objects, including biological ones.

Traditionally used single-position radars are ineffective in conditions of a large number of reflections that interfere with and low speed of movement of detected objects (people). The use of several such radars is impractical due to their rather high complexity and cost. In addition, it is impossible to ensure the secrecy of such systems. The construction of radar surveillance systems in the form of semi-active bistatic, including educational, radar systems is promising for the described conditions. One of the important issues in the construction of semi-active bistatic systems is the substantiation of the parameters of external illumination signals and the assessment of the attainable characteristics of such systems when using them.

The analysis and definition of the requirements for the characteristics of the illumination signals is carried out. In addition, consider the features of using signals from modern emitting systems in semi-active radars. The basic parameters of the signals are given - the bandwidth, the pulse duration (spectrum width), the power at the transmitter output, the frequency range in which the system operates. The advantages and disadvantages of semi-active radar stations (SA RS), which use such signals, are described.

Variants of semi-active bistatic systems with external illumination are determined. The widespread use of modern digital language and telecommunication systems provides the SA RS with effective illumination signals with good correlation properties, which makes it possible to obtain the necessary technical characteristics in a variety of application conditions.
\end{abstract}

Keywords: semi-active radars, illumination signal, uncertainty function, biological objects, covert surveillance.

DOI: $10.21303 / 2461-4262.2021 .001607$

\section{Introduction}

The planet's surface is surrounded by a multitude of radio signals for various purposes: radio broadcasting, cellular communications, television, satellite navigation signals, radio relay signals, and the like. The transmission of the listed signals is carried out via wireless communication 
channels, as a result of which, when the signal propagates, they are reflected from many objects on the route, including from ground or targets close to them. Therefore, signals from known sources can be used to obtain radar information in semi-active radar stations (SA RS).

The common disadvantages of all classic radars include the detection of their operation by the enemy at ranges significantly exceeding the range of these radars. In addition, there is a great tendency for them to operate by means of electronic suppression of the enemy. Therefore, radars built on the principle of semi-active bistatic radar are of considerable interest in modern conditions.

In addition, special attention is paid to radars designed to detect small-sized objects, including biological ones, in open, heavily rugged or wooded areas. Such a task arises when creating security systems, combat observation systems, and anti-terrorist systems.

To create such systems, various physical effects and methods are used [1]: video and radar surveillance, perimeter security systems, security and fire alarm systems, access control systems. Each system has its own advantages and disadvantages related to the environment, weather conditions, and time of day.

Thus, the solution of problems associated with the research and development of SA RS for detecting ground targets is of great scientific importance. The solutions obtained will make it possible to use the SA RS for solving problems of covert detection, determining the location and classifying ground objects in conditions of various types of interference. This determines the relevance of the article, which examines the main factors affecting the range of the system, the advantages and disadvantages of illumination signals that are used in the SA RS.

Analysis of scientific literature shows that the use of the principles of spaced apart (semiactive, bistatic) radar for solving the problem of detecting targets, in most air targets, is devoted to a large number of scientific developments. So in works [2-5], the issues of application of classical spaced apart, including bistatic, systems for detecting air, aerospace objects, including ballistic missiles in the active phase of flight, are considered. The principles of construction are given and the capabilities of promising multi-position radar systems (MPRS) of air defense (AD), which will allow solving qualitatively new tasks for covert observation and control of airspace, are assessed.

In works $[6,7]$, the issues of the features of construction of bistatic systems of semi-active location in the radiation field of cellular communication systems, radio broadcasting and television of ground and space-based systems are highlighted. In [6], this approach is used to detect low-altitude radar objects, and in [7] - objects on the sea surface.

However, all of the above works did not touch upon the issues of identifying ground targets, let alone biological ones. And only in the last 3...5 years, work began to appear on the application of spaced-apart radar methods for observing small-sized objects near or on the Earth's surface [8, 9]. In these works, more attention is paid to the influence of the underlying earth's surface, as one of the sources of signal reflection.

In works $[10,11]$, the principles of construction and the issues of practical implementation of systems of semi-active radar airborne objects using illumination signals from external sources are proposed. In addition, in these works, the prospects for the SA RS use for the protection of important objects and monitoring of the territory are considered. Generally speaking, the issue of illumination of radar objects has always been in the field of vision of developers. For example, transmitters of systems for various purposes [12-15], including space-based ones [16], were used as illumination sources.

Radars for detecting biological objects appeared as a result of developments at the intersection of radiophysics and biology. Papers [17-24] describe in detail ground-based radars, built according to the classical principle of active radar, according to which the transmitter-receiver operates on a common antenna. In these works, the issue of secrecy of the functioning of the system is not discussed at all, as well as there is no information about the SA RS, which can be used for covert observation of the security zone of important state facilities.

The use of semi-active radar biological objects was touched upon in $[25,26]$. In them, consider possible ways to implement the observation of biological objects using semi-active bistatic radar methods. However, it has been improved not to consider the features of using the signals of modern radiating systems in semi-active radars. 
All this allows to assert that it is expedient to conduct a study devoted to the analysis of the possibility of using the methods of semi-active spaced radar of biological objects for the organization of covert surveillance under any weather conditions in the security system of important state facilities.

The aim of research is to analyze the peculiarities of using signals from modern emitting systems in semi-active radars for monitoring biological objects.

To achieve the aim, the following objectives are set:

- analysis and definition of requirements for the characteristics of signals that can be used as those that highlight;

- selection of the illumination source and assessment of the attainable characteristics and parameters of semi-active bistatic radar stations.

\section{Materials on the features of using signals from modern emitting systems in semi-active} radars for monitoring biological objects, and methods of their selection

2. 1. Determination of the requirements for the characteristics of signals used in semiactive radar systems

Traditionally used single-position (monostatic) radars for detecting moving objects in conditions of a large number of reflections that interfere with and a low speed of movement of vivid objects (people) are ineffective. The use of several such radars is impractical due to their rather high complexity and cost. In addition, it is impossible to ensure the secrecy of the operation of such detection systems, which is an important condition for radar surveillance.

The construction of radar surveillance systems in the form of bistatic $[4,5]$, including educational, radar systems, is promising for the described conditions.

Of particular interest is the use of transmitters external to the planned radar system as a source of illumination. Such transmitters can be a ground-based and space-based radio and television transmission center operating with analog and digital (which is better) signals, radio navigation systems transmitters, cellular communication systems and radio relay transmitters, etc. In this case, the new system acquires undeniable advantages:

- expensive transmitting device of the locator is excluded, since «free» radiation of industrial systems for other purposes is used;

- as a consequence of the first, the power consumption of the entire system is significantly reduced, since the main consumer is the transmitter;

- almost complete secrecy of the functioning of the new system is ensured, since the radiation of a specialized transmitter is excluded;

- a significant (almost all) part of the constituent elements of the new system can be built on mastered and such widely produced industrial products, and also significantly reduces the cost of developing the system.

It should be noted that the proposed means and methods for solving the problems of detecting an intruder by means of radar by no means cancel the means and complexes that have been created and are in service, but only increase their capabilities.

For use in semi-active radar systems, the signals from the above sources must have the following characteristics:

- signal must have characteristics that allow detecting targets and evaluating their parameters; for sufficient time resolution, signals must have an appropriate spectrum width;

- transmitters of systems which signals are used in a semi-active radio surveillance system must have antennas with a wide radiation pattern;

- placement of transmitters and the mode of their radiation should provide illumination of a given area with sufficient power;

- coordinates of the source of radio emission must be known.

In most cases, there are no difficulties in meeting these requirements. Thus, in order to ensure the characteristics of the signals that are illuminated, the problem arises of choosing a illumination source for a particular system. Let's consider the main characteristics of the emitted signals in more detail. 


\section{2. Assessment of the achievable characteristics and parameters of various sources of} illumination signal used in bistatic radar of biological objects

The potential characteristics of on-board radar substantially depend on the type of illumination signal used, namely, on the structure of its uncertainty function (UF). The width of the main UF peak determines the signal resolution in terms of range and speed: the narrower the peak, the higher the resolution. The UF side lobes (SL) mask a weak signal when it is detected against a strong background. Side lances create parameter measurement ambiguity.

Therefore, one should strive to ensure that the main UF peak was as narrow as possible along both axes, the SL level was as low, and the side spears were outside the working area in terms of range and radial velocity.

Illumination transmitters must have a coverage area, covering the area of finding potential targets, continuous (up to round-the-clock) radiation mode and a sufficiently high power. These requirements are best met by signals from terrestrial radio and television broadcasting systems.

Less explored is the use of satellite (language, navigation, communication) and terrestrial telecommunication systems (microwave communication lines, mobile telephony, Wireless Fidelity (Wi-Fi), Worldwide Interoperability for Microwave Access (WiMAX)). This is due to the fact that such semi-active radar systems have less power at the receiving point, they can be more focused and provides less availability.

Analog broadcasting is conducted in the meter wave range at frequencies of $66 . .74 \mathrm{MHz}$ (ultrashort waves (USW)) and 88...108 MHz (Frequency Modulation (FM)). The signal spectrum is nominally about $50 \mathrm{kHz}$. However, since the spectrum of the frequency-modulated signal is theoretically infinite, in reality the signal occupies a bandwidth of more than $50 \mathrm{kHz}$, being limited by components that are sufficiently large in power, the spectrum is considered to be up to $190 \mathrm{kHz}$ [11]. A signal bandwidth of $50 \mathrm{kHz}$ corresponds to a potentially observable resolution in MPRS of $3 \mathrm{~km}$. For observation of ground targets, such a resolution is unacceptable, therefore, it is not possible to consider such a signal (how it illuminates) further.

Analog television occupies frequencies of $48 \ldots 100 \mathrm{MHz}$ (1...5 TB channels), $174 \ldots 230 \mathrm{MHz}$ (6...12 channels), $470 \ldots 790 \mathrm{MHz}\left(21 \ldots 60^{\text {th }}\right.$ channels). Fig. 1 shows the spectrum of analog television, consisting of a luminance signal, a color signal, and analog and digital audio. The bandwidth of the broad of them, the luminance signal, is $5.5 \mathrm{MHz}$, which corresponds to a resolution of $27 \mathrm{~m} \mathrm{[9].}$

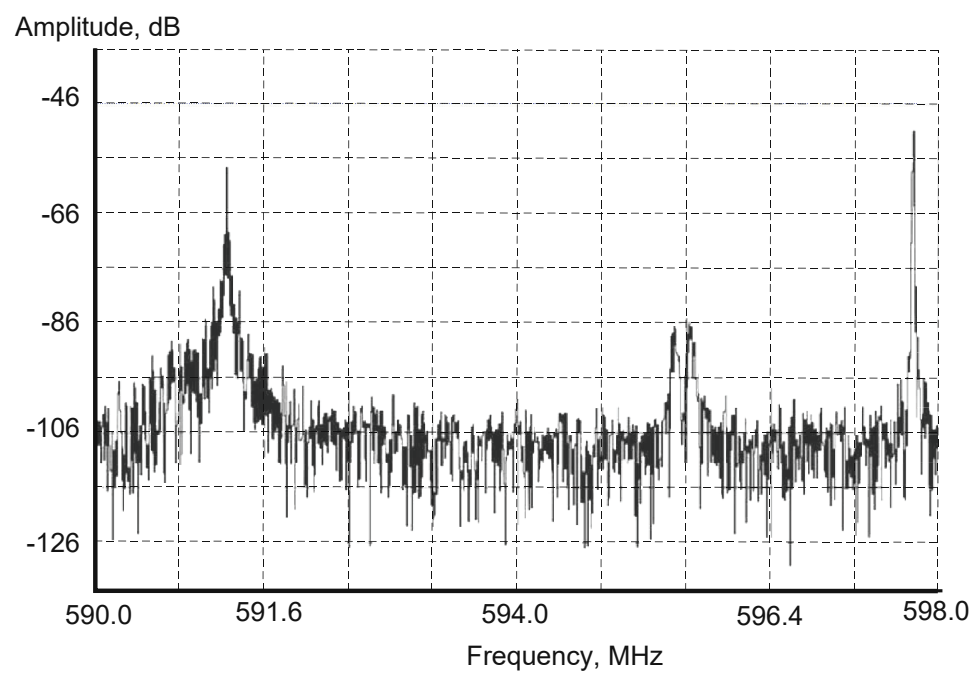

Fig. 1. Spectrum of analog TV signal. Frequency $591.25 \mathrm{MHz}$ - luminance signal $595.6 \mathrm{MHz}-$ color-difference signals; $597.75 \mathrm{MHz}$ - sound signal

It should be noted that the authors of [9] used a band of $5.5 \mathrm{MHz}$, which is not true - the band of the brightness signal at the half power level (Fig. 1) does not exceed $150 \ldots 200 \mathrm{kHz}$.

The power of the transmitters can reach $1 \mathrm{MW}$ of effective isotropically emitted power, provides a power flux density of $51 \mathrm{dBW} / \mathrm{m}^{2}$ at a distance of $100 \mathrm{~km}$ (in line of sight and in the 
absence of losses along the propagation path). The presence of sync signals following $64 \mu$ s leads to an uncertainty in the range measurement, which is $9.6 \mathrm{~km}$.

Now Ukraine has switched to digital TV broadcasting in the T2 standard, the signal bandwidth is $8 \mathrm{MHz}$.

Digital signals of terrestrial broadcasting standards Digital Video Broadcasting - Terrestrial (DVB-T) (television) and Digital Audio Broadcasting (DAB) (radio) are close to noise-like. Such digital signals have a close-to-rectangular spectrum, providing a lower level of the UF power supply in comparison with analog signals. Fig. 2, $\boldsymbol{a}$ shows the spectrum, and Fig. 2, $\boldsymbol{b}$ - SL signal of Digital Video Broadcasting - Second Generation Terrestrial (DVB-T2). Other important advantages of digital signals are wide bandwidth (that is, better range resolution) and independence of their properties from the plot.
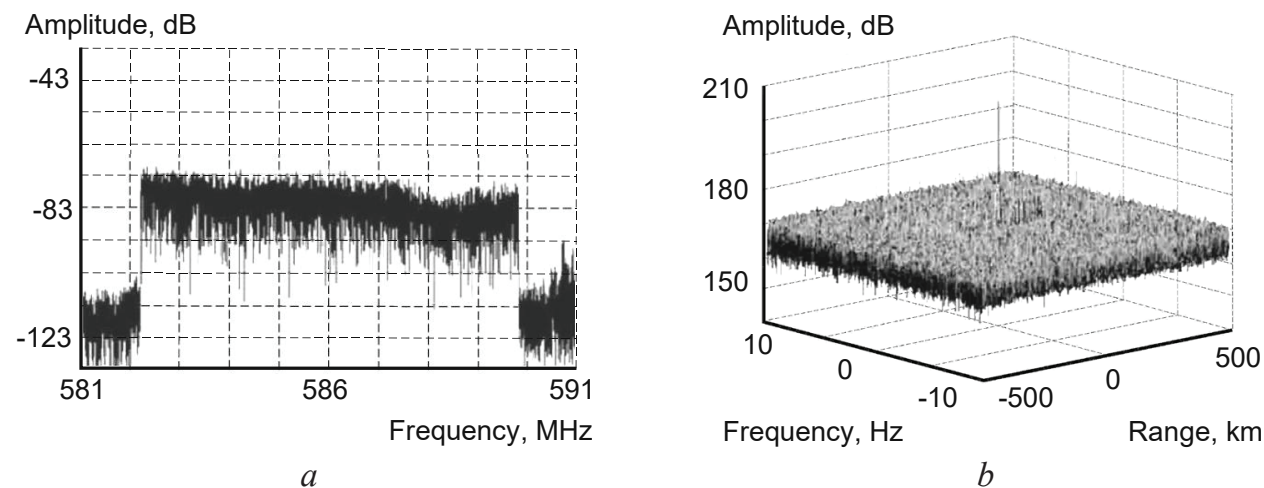

Fig. 2. Signal of terrestrial broadcasting of DVB-T standards: $a$ - spectrum of DVB-T2 signal; $b$ - ambiguity function of DVB-T2 signal

The combination of these advantages makes the use of digital signals predominant over analog signals, despite the lower power and complex processing.

The DAB digital terrestrial broadcasting standard uses frequencies in the $200 . .250 \mathrm{MHz}$ range, the transmitter power is about $1 \mathrm{~kW}$, which is significantly lower than in similar FM transmitters [7].

Table 1 shows the parameters of one of the DVB-T2 signals in $8 \mathrm{k}$ mode.

Table 1

Parameters of DVB-T2 signal in 8k mode

\begin{tabular}{cccc}
\hline $\begin{array}{c}\text { Frequency, } \\
\mathbf{M H z}\end{array}$ & $\begin{array}{c}\text { Maximum range } \\
\text { resolution, } \mathbf{m}\end{array}$ & $\begin{array}{c}\text { Effective spectrum } \\
\text { width, } \mathbf{M H z}\end{array}$ & $\begin{array}{c}\text { UF SL maximum power supply } \\
\text { level, dB }\end{array}$ \\
\hline 583 & 20 & 7.61 & -26.3
\end{tabular}

To transmit digital signals, television channels from 6 to 12 and from 21 to 69 can be used. Usually, one or two channels are allocated for broadcasting the DVB-T2 standard, each of which transmits the so-called multiplex, consisting of eight language TV channels and several radio channels ... Typical transmitter power for this standard is $8 \mathrm{~kW}$.

Now, digital terrestrial television signals are considered by specialists as the main ones for use in bistatic radar systems. Its advantages:

- good UF properties (low SL power, high range resolution due to a wide spectrum, independence of signal properties from message content, that is, stability of MPRS characteristics);

- high availability due to the development of terrestrial broadcasting systems.

As the main disadvantage, let's note the relatively low power of the transmitters, as a result of the shorter operating range compared to analog systems. Note also that information on the use of these signals for bistatic location of ground targets is extremely limited.

The technical solutions used in the Digital Radio Mondiale (DRM) digital broadcasting system ensure high stability of signal reception in the presence of adverse influencing factors 
in the transmission channels (interference, fading, multipath propagation, etc.). This allows for high-quality signal reception in stationary and mobile conditions, as well as in cars or other moving objects [10]. In the DRM system, broadcasting is usually carried out in a $10 \mathrm{kHz}$ band, which clearly does not satisfy the range resolution.

Short-wavelength (SW) language transmitters emit more power than stations in other bands. A typical value of the energy potential of a SW radio station $\left(P_{t} \cdot G_{t}\right)$ is $50 \mathrm{MW}[12]\left(P_{t} \cdot\right.$ - the average transmitter power, $G_{t}$ ) - the antenna gain).

Cellular telephone networks Global System for Mobile Communications (GSM) operate at frequencies of $900,1800 \mathrm{MHz}$ and higher. The $25 \mathrm{MHz}$ bandwidth for a single station is divided into 125 channels of $200 \mathrm{kHz}$, which is the illumination signal bandwidth [13]. Each of the carriers is divided into 8 time slots with a duration of $577 \mu \mathrm{s}$. The transmitter power, depending on the class (from 1 to 5 ), is from 50 to $0.8 \mathrm{~W}$.

Thus, GSM cellular communication provides MPRS with better resolution than FM broadcasting, but worse than digital TV. In addition, the frequency is allocated to the subscriber dynamically, so this particular station at the moment and at a particular frequency may not emit a signal. For this reason, mobile networks do not provide full availability of the illumination field.

In $3 \mathrm{G}$ networks, the signal frequency is about $2 \mathrm{GHz}$, the nominal frequency distance between channels is $5 \mathrm{MHz}$. Modulation with an effective bandwidth of $3.84 \mathrm{MHz}$, which can already find application in on-board radars.

Antennas of base station transmitters have a sector of $120^{\circ}$ (there can be one, two or three antennas), the radiation elevation angle is directed downward to exclude radiation into the upper hemisphere. The points are separated by an average of $10 \mathrm{~km}$, the radiated power is about $100 \mathrm{~W}$, in cities, towers are installed more often, and the power is made half as low. The main development trend is to install transmitters of lower power, but more often.

GSM disadvantages - relatively low power and availability, mediocre signal properties in comparison with other digital standards; the advantage is a large coverage area. Cellular signals are still rarely used in bistatic locations, the most famous is the Celldar system.

Wi-Fi wireless access network is a family of standards for transmission of digital data streams over radio channels. Wi-Fi technology is widely used to create wireless networks that provide Internet access in a wide variety of environments.

The main advantages of using Wi-Fi transmitter signals in MPRS are high range resolution, provided by a wide signal bandwidth, large coverage area and high availability. According to experts, Wi-Fi is ideal for creating surveillance systems over short distances (tens to hundreds of meters).

Real signal bandwidths for Direct Sequence Spread Spectrum (DSSS) are about $11 \mathrm{MHz}$ for Orthogonal Frequency-Division Multiplexing (ODFM) - about $17 \mathrm{MHz}$, which provides a resolution of 13 and $9 \mathrm{~m}$, respectively.

When using Wi-Fi in the radar scheme, the following technical difficulties arise. First of all, the UF has a rather unfavorable structure - a high SL and local peaks, which leads to masking of weak reflections and range limitations. To overcome this effect, special processing methods should be used.

There are other problems in the construction of MPRS Wi-Fi. Many devices operate in the $2.4 \mathrm{GHz}$ band, for example, they support another standard for wireless data transmission, the Bluetooth standard, or microwave ovens.

Let's note that such systems have a fairly short range (tens to hundreds of meters) and are tied to certain zones where Wi-Fi is present. However, if necessary, the access point can be additionally placed in the desired place to provide the required range. In the MPRS, a direct signal is needed. Two options are possible here [25]:

- in the first, a separate direct signal channel is created, and in a system with Wi-Fi, taking into account the locality of the observation area, it is possible to provide a sufficiently small distance between the transmitter and receiver;

- in the second, the direct signal is separated from the signals received in the reflected channel, which is the only one. 
Further processing corresponds to the coherent MPRS - rejection of the direct signal from the reflected channel, calculation of a two-dimensional FN, target detection and construction of the trajectory of the observed object.

WiMAX wireless access network provides significantly higher efficiency, wide signal bandwidth and good availability [7]. The protection zone of one WiMAX network intermediary can reach $50 \mathrm{~km}$ directly, but significantly depends on the channel mode. In general, the standard provides for operation in the frequency range $2 \ldots 11 \mathrm{GHz}$ with bands from 1.25 to $20 \mathrm{MHz}$.

Satellite radio systems can be created in three categories: low-orbit (LO) - altitude $300 \ldots 1000 \mathrm{~km}$, medium-orbit (MO) - altitude $21000 \mathrm{~km}$ and geostationary (GEO) - altitude $35786 \mathrm{~km}$. Table 2 shows the parameters of some satellite sources of the illumination signal [16].

Table 2

Parameters of satellite signal of illumination sources

\begin{tabular}{|c|c|c|c|c|}
\hline Type & Name & Orbit & Frequency range, $\mathrm{MHz}$ & Power flux density, $\mathrm{dBW} / \mathrm{m}^{2}$ \\
\hline Radar & Radarsat-2 & $\mathrm{LO}$ & $3400 \ldots 7075$ & -53 \\
\hline \multirow[t]{6}{*}{ Communication } & DVB-S (Astra) & \multirow{4}{*}{ GEO } & \multirow{3}{*}{$1930 \ldots 2700$} & -111 \\
\hline & DVB-SH & & & -97 \\
\hline & Inmarsat-4 & & & -95 \\
\hline & Thuraya & & $1452 \ldots 1710$ & $-118 \ldots-106$ \\
\hline & Iridium & \multirow{2}{*}{ LO } & & -108 \\
\hline & Globalstar & & $1930 \ldots 2700$ & -97 \\
\hline \multirow[t]{3}{*}{ Navigational } & Global Positioning System (GPS) & & & -130 \\
\hline & ГЛОНАСС & MO & $1452 \ldots 1710$ & $-129 \ldots-131$ \\
\hline & Galileo & & & -128 \\
\hline
\end{tabular}

Geostationary satellites, constantly being above the same point, provide availability close to unity, but have a lower power density compared to LO.

The prospects for the use of signals in terrestrial on-board radars from relatively new space systems of digital mobile television broadcasting look more optimistic. These systems are designed to work with mobile users who can't use large antenna systems. Signals of significantly higher power are used in these systems than for stationary devices. In addition, such systems provide adequate coverage and availability.

In the future, it is on these satellites that circuit solutions remain traditional.

Among these systems are EutelsatW2A and Inmarsat 1-4 EMEA, which are available in Europe. Some parameters of the satellites Eutelsat and Inmarsat [25] are given in Table 3.

Table 3

Parameters of Eutelsat and Inmarsat satellites

\begin{tabular}{ccc}
\hline Parameter & EutelsatW2A & Inmarsat 1-4 \\
\hline Latitude/Longitude & $0.01^{\circ} \mathrm{N} / 10.05^{\circ} \mathrm{E}$ & $0 \% 25.12^{\circ} \mathrm{E}$ \\
Height, $\mathrm{km}$ & 3540 & 35800 \\
Power flux density, $\mathrm{dBW} / \mathrm{m}^{2}$ & 72 & 67 \\
Carrier frequency, $\mathrm{GHz}$ & 2.17 & 1.50 \\
Signal bandwidth, $\mathrm{MHz}$ & 2 & 0.2 \\
Coverage area & Europe & Europe, Africa
\end{tabular}

Computer simulations carried out in [15] showed that in an MPRS using these illumination signals, one can expect an aircraft to be detected at ranges of up to $50 \mathrm{~km}$ (Inmarsat) and $90 \mathrm{~km}$ (Eutelsat). 
Simulation parameters: effective target scattering area $13 \mathrm{dBm}$, antenna gain $21 \mathrm{~dB}$, accumulation time $1 \mathrm{~s}$, receiver noise level $5 \mathrm{~dB}$.

According to the currently generally accepted point of view, given the noted shortcomings, it is still difficult to use space-based illumination transmitters to solve traditional radar problems. The issues of using space illumination for locating ground targets require further consideration.

The materials [11] provide a generalized material on diversity systems using signals from existing broadcasting and television stations as those that are probed. These data are given in Table 4.

The energy characteristics of the illumination signal sources are collected from various sources and are given in Table 5.

Table 4

Parameters of signals of broadcasting and television stations

\begin{tabular}{cccc}
\hline Signal & Range solution, $\mathbf{k m}$ & Side lobe level in range, dB & Side lobe level by velocity, dB \\
\hline Language (FM) & 16.5 & -19.1 & -46.5 \\
Music (FM), classical/rock & $5.8 / 6.55$ & $-23.9 /-12.0$ & $-32.5 /-26.0$ \\
Analog TV & 9.61 & -0.2 & -9.1 \\
Digital television & 1.72 & -18.5 & -34.6 \\
GSM 900/1800 & $1.8 / 2.62$ & $-9.3 /-6.9$ & $-47 /-44$
\end{tabular}

Table 5

Energy characteristics of illumination signals

\begin{tabular}{cccc}
\hline Signal source & Frequency, $\mathbf{M H z}$ & Band, $\mathbf{M H z}$ & Power, $\mathbf{k W t}$ \\
\hline FM and USW & $66 \ldots 108$ & $0.003 \ldots 0.02$ & $0.1 \ldots 4$ \\
Analog TV & $50 \ldots 800$ & $0.1 \ldots 0.2$ & up to 50 \\
Cellular GSM & 900,1800 & up to 25 & 0.02 \\
3G communication systems & 1920,2110 & 5 & 0.02 \\
Digital TV & $174 \ldots 834$ & 8 & up to 10
\end{tabular}

In general, to determine the energy potential of a particular illumination option, one needs estimation calculations with averaged initial data.

\section{Results of research on the principles of using bistatic radar for solving the problem of detecting biological objects and their discussion}

Studies have shown that when observing ground targets, the resolution in a system with an analog broadcasting signal is unacceptable, therefore such a signal (which illuminates) is not considered.

The presence of sync signals in analog television transmitters following $64 \mu$ s leads to the appearance of an uncertainty in the range measurement, which is $9.6 \mathrm{~km}$. In addition, the resolution for observing biological objects is also insufficient - such signals are impractical to use.

Digital signals of terrestrial broadcasting are close to noise-like ones, therefore, a low level of UF SL, better range resolution and independence of properties from the plot are provided. The combination of these advantages makes the use of digital signals preferable, despite the lower power and more complex processing.

Despite the large coverage area, cellular signals are still rarely used in bistatic locations due to the relatively low power and availability, as well as mediocre signal properties compared to other digital standards.

Signals of Wi-Fi and WiMAX wireless access networks provide high range resolution due to wide signal bandwidth, large coverage area, high availability. But a high SL level and local peaks lead to masking of weak reflections and range limitations when working on ground targets. 
For well-known reasons, low- and mid-orbit satellites are not widely used in MPRS. According to the currently generally accepted point of view, given the noted shortcomings, it is still difficult to use space-based MPRS to solve traditional radar problems. The prospects for using signals from relatively new space systems of digital mobile television broadcasting look optimistic. The issues of using space half-light for locating ground targets require further consideration. Among the organizations dealing with these issues, there are mainly universities and scientific units of the military departments.

The peculiarities of the results obtained are in the proof of the presence of various radio devices among the emissions that can be used to solve the problem of detecting biological objects (intruders) in the observation or protection zone, including especially important objects.

Among the limitations of the applicability of the results, it should be noted that only the upper estimates are valid, that is, the potential capabilities of a particular observation system using bistatic radar methods. In the future, these restrictions can be removed by a detailed study of the systems' performance under conditions of action of various kinds of obstacles of natural and artificial origin.

In further research, one will have to face certain difficulties of a mathematical (transition to non-stationary processes) and experimental character. The latter is explained by the lack of adequate funding for the purchase of the necessary equipment and equipment.

\section{Conclusions}

1. Research of passive coherent systems with illumination signals of USW range of digital television is carried out in the USA, Great Britain, Russia, France, Germany, Poland, Norway, South Africa, China, Iran and other countries. This can be explained both by the high expected technical characteristics of coherent SA RS of this range (due to the properties of the signal), and by the simplicity and low cost of the design (in comparison with other USW radars). And now the most popular USW range, and in it - illumination signals from digital television.

Such plants have a number of advantages: lower cost of production, placement and operation; absence of harmful effects on the environment and interference with other radio-technical devices; almost complete secrecy; they do not need separate frequencies. The characteristic features of the SA RS determine the high potential of their application for the protection of important objects, monitoring of perimeters and territories, including with the creation of a surface radar field.

2. As a result of the research carried out, it was found that SA RS using illumination signals from third-party sources are considered promising means of detecting and tracking ground, including biological, objects. For further research, let's leave three options for bistatic systems with external illumination - a ground transmitter with a digital signal of the T2 format, a space transmitter with a digital signal, and a transmitter for a cellular communication system. In other ranges of work on semi-active coherent location is less.

It is the choice of one of the listed illumination signals that is the first step for further scientific research to justify the SA RS structure for the protection of important objects, monitoring the perimeters, their construction and implementation into a prototype.

The widespread use of modern digital language and telecommunication systems provides the SA RS with effective illumination signals with good correlation properties, which makes it possible to obtain the necessary technical characteristics in a wide variety of application conditions.

\section{References}

[1] Magauenov, R. G. (2004). Sistemy ohrannoy signalizatsii: osnovy teorii i printsipy postroeniya. Moscow: Goryachaya liniya Telekom, 494. Available at: https://www.techbook.ru/book.php?id_book=946

[2] Kondratenko, A. P. (2002). Rol' i mesto netraditsionnoy radiolokatsii v sisteme kontrolya vozdushnogo prostranstva. Zbirnyk naukovykh prats KhVU, 1 (39), 87-90.

[3] Anoshkin, I. M. (2007). Zarubezhnye mnogopozitsionnye sistemy radiolokatsii skrytogo kontrolya vozdushnogo prostranstva. Nauka i voennaya bezopasnost', 1, 28-33. Available at: http://militaryarticle.ru/nauka-i-voennaya-bezopasnost/2007/11986zarubezhnye-mnogopozicionnye-radiolokacionnye

[4] Kulpa, K. (2014). Passive Radar. Radar Symposium 2014. KACST, Riyadh Saudi Arabia. Available at: https://slideplayer.com/ slide/3432556/ 
[5] Griffiths, H. (2013). Bistatic and Multistatic Radar. IEEE AESS Distinguished Lecture. ETH Zurich, 78. Available at: https:// pdfs.semanticscholar.org/3f61/fe08e00103aa8c17425c386d47a99cc40d64.pdf

[6] Demidyuk, A., Demidyuk, E. (2013). Skrytiy «Rubezh» vozdushnogo kontrolya. Novye resheniya staryh problem malovysotnoy lokatsii. Voenno-promyshlennyy kur'er, 45 (513). Available at: http://vpk-news.ru/articles/18242

[7] Chetty, K., Woodbridge, K., Guo, H., Smith, G. E. (2010). Passive bistatic WiMAX radar for marine surveillance. 2010 IEEE Radar Conference. doi: https://doi.org/10.1109/radar.2010.5494627

[8] Kovalev, A. N., Kovalev, F. N. (2014). Statistical characteristics of target location finding error in bistatic forward scattering radars. Radioelectronics and communications systems, 57 (3), 3-9. doi: https://doi.org/10.20535/s0021347014030017

[9] Barhatov, A. V., Verem'ev, V. I., Vorob'ev, E. N. et. al. (2016). Passivnaya kogerentnaya radiolokatsiya. Sankt-Peterburg: Izdatel'stvo «LETI», 162. Availableat: https://search.rsl.ru/ru/record/01008926589

[10] Kutuzov, V. M., Barhatov, A. V., Bezuglov, A. V., Verem'ev, V. I., Konovalov, A. A., Kovalev, D. A. (2012). Osnovy proektirovaniya mnogopozitsionnyh dekametrovyh RLS prostranstvennoy volny. Sankt-Peterburg: Izdatel'stvo «LETI», 191. Available at: http://letiizdat.ru/izdaniya/nauchno-tehnicheskaya-literatura/monografii/2012/osnovy-proektirovaniya

[11] Griffiths, H. D. (2009). Passive bistatic radar and waveform diversity. Lecture Series Paper 3, Waveform Diversity for Advanced Radar Systems, NATO Science and Technology Organization, RTO Educational Notes. RTO-EN-SET-119 (2009). Available at: https://apps.dtic.mil/dtic/tr/fulltext/u2/a567763.pdf

[12] Thomas, J. M., Baker, C. J., Griffiths, H. D. (2007). DRM signals for HF passive bistatic radar. IET International Conference on Radar Systems 2007. doi: https://doi.org/10.1049/cp:20070642

[13] Tan, D. K. P., Sun, H., Lu, Y., Liu, W. (2003). Feasibility analysis of GSM signal for passive radar. Proceedings of the 2003 IEEE Radar Conference (Cat. No. 03CH37474). doi: https://doi.org/10.1109/nrc.2003.1203436

[14] Sutcuoglu, O., Hassoy, B. (2013). Airborne passive radar application: Interactions with space. 2013 6th International Conference on Recent Advances in Space Technologies (RAST). doi: https://doi.org/10.1109/rast.2013.6581190

[15] Cristallini, D., Caruso, M., Falcone, P., Langellotti, D., Bongioanni, C., Colone, F. et. al. (2010). Space-based passive radar enabled by the new generation of geostationary broadcast satellites. 2010 IEEE Aerospace Conference. doi: https://doi.org/ 10.1109/aero.2010.5446694

[16] Griffiths, H. D., Baker, C. J., Baubert, J., Kitchen, N., Treagust, M. (2002). Bistatic radar using satellite-borne illuminators. RADAR 2002. doi: https://doi.org/10.1109/radar.2002.1174642

[17] Malinin, M. (2016). Osnovnye napravleniya razvitiya za rubezhom radiolokatsionnyh stantsiy razvedki nazemnyh dvizhushchihsya tseley. Zarubezhnoe voennoe obozrenie, 11, 47-53. Available at: http:/factmil.com/publ/strana/velikobritanija/osnovnye napravlenija_razvitija_za_rubezhom_radiolokacionnykh_stancij_razvedki_nazemnykh_dvizhushhikhsja_celej_2016/9-1-0-1076

[18] Mobile complex of surface recognition and ECM «JAB». Available at: http://ust.com.ua/en/mobile-complex-of-surfacerecognition-and-ecm-jab/

[19] Radiolokatsionniy kompleksohrany obektov. Availableat:http://www.umirs.ru/catalog/stationary_complex/radiolokatsionnyykompleks-okhrany-obektov/

[20] Mosalev, V. (2000). Stantsii radiolokatsiy razvedki nazemnyh dvizhushchihsya tseley. Zarubezhnoe voennoe obozrenie, 10, 20-22. Available at: http://militaryarticle.ru/zarubezhnoe-voennoe-obozrenie/2000-zvo/6678-radiolokacionnye-stanciirazvedki-nazemnyh

[21] Zaytsev, N. A., Platov, A. V., Potapov, V. A. (2014). Radiolokatsionnye stantsii razvedki nazemnyh dvizhushchihsya tseley. Sovremenniy uroven' i osnovnye napravleniya razvitiya. Vestnik Kontserna PVO «Almaz-Antey», 1, 41-44. Available at: http://www.npostrela.com/upload/Antey.pdf

[22] Radar «BARSUK-A». Available at: http://ust.com.ua/en/item/radar-barsuk-a/

[23] Radiolokator «LC 111» (Lis-1). Available at: http://www.bnti.ru/des.asp?itm=5258\&tbl=19.01.02

[24] Radar-obnaruzhitel' lyudey za pregradami «RO-400». Available at: http://www.bnti.ru/des.asp?itm=5053\&tbl=02.03.03

[25] Kondratenko, O. P. (2018). Use of methods of the bioradar-location for observation of biological objects. The Collection of Scientific Works of the National Academy of the National Guard of Ukraine, 1 (31), 19-26. Available at: http://znp.nangu.edu.ua/ article/view/138489/164858

[26] Abramov, A. V., Anishchenko, L. N., Amosova, A. I. (2018). Bioradiolokatsiya. Moscow: MGTU im. Baumana, 396. Available at: https://obuchalka.org/20181025104763/bioradiolokaciya-abramov-a-v-2018.html 